\title{
ЗАСТОСУВАННЯ ЕНТЕРОСОРБЕНТУ “КАРБОЛАЙН” ДЛЯ КОРЕКЦІЇ ОКИСНЮВАЛЬНИХ ПРОЦЕСІВ У ЩУРІВ РІЗНОГО ВІКУ, УРАЖЕНИХ НАТРІЮ НІТРИТОМ НА ТЛІ ТЮТЮНОВОЇ ІНТОКСИКАЦІЇ
}

Вступ. Одним із пріоритетних напрямків токсикології та медицини є вивчення особливостей і механізмів комбінованої дії ксенобіотиків - чинників ризику багатьох екологічно залежних хвороб. Під впливом екстремальних фракторів різного походження (важкі метали, нітрати, пестициди, тютюнокуріння, алкоголь) інтенсифрікується утворення активних форм кисню (АФК), що призводить до розвитку оксидативного стресу в організмі, який супроводжується активацією процесів пероксидного окиснення ліпідів та окиснювальної модифрікації білків. За даних умов широко використовують засоби з антиоксидантними та сорбтивними властивостями.

Мета дослідження - оцінити ефрективність використання ентеросорбенту "Карболайн" та його вплив на окиснювальні процеси в організмі щурів різного віку, уражених натрію нітритом на тлі 30-денної тютюнової інтоксикації.

Методи дослідження. За умов ураження щурів різного віку натрію нітритом на тлі тютюнової інтоксикації визначали вміст АФК у популяції нейтрофрілів крові, отриманих за допомогою чентрифуугування на подвійному градієнті щільності 1,077 і 1,093 фріколу-верографріну, вміст ТБК-активних продуктів у реакції з тіобарбітуровою кислотою та окисну модифрікацію білків за вмістом 2,4-динітрофренілгідразонів.

Результати й обговорення. Найвищі показники активності вільнорадикальних процесів відмічено після ураження натрію нітритом за 72 год до припинення 30-денної інтоксикації тютюновим димом. Статевонезрілі та старечі щури виявились значно чутливішими до дії токсикантів, ніж зрілі тварини. Використаний з метою пригнічення активованих окиснювальних процесів ентеросорбент "Карболайн" незначно нормалізував досліджувані показники. Спостерігали тенденцію до зниження вмісту АФК у крові, ТБК-активних продуктів та 2,4-динітрофренілгідразонів у досліджуваних тканинах.

Висновок. Карболайн доцільно включити до комплексного лікування отруєнь різного генезу.

КЛЮЧОВІ СЛОВА: натрію нітрит; тютюновий дим; активні фоори кисню; ліпопероксидація; окиснювальна модифрікація білків; карболайн.

ВСТУП. Куріння сьогодні-одна з найсерйозніших проблем, з якими борються в усьому світі. Тютюнокуріння є причиною виникнення низки захворювань та передчасних смертей $[1,2]$. Це стосується насамперед раку легенів та інших видів онкозахворювань, серцево-судинних патологій, загострення та ускладнення багатьох інших патологічних станів (пневмонії, емфріземи, хронічного бронхіту) [3-5].

У результаті антропогенного впливу на природу в навколишньому середовищі накопичуються фрактори, що спричиняють патогенну дію на здоров'я людини і тварин. Серед речовин, що забруднюють довкілля, за об'ємом використання азотні добрива займають провідне місце. В Україні після деякого спаду виробництво та застосування азотних добрив постійно збільшу(с П. Г. Лихацький, Л. С. Фіра, 2017. ються, в результаті чого зберігається тенденція до ускладнення екологічної ситуації та зростає актуальність досліджень, пов'язаних із цією проблемою. Надмірне накопичення азотовмісних сполук у довкіллі призводить до підвищення вмісту нітратів у ґрунті, водах та сільськогосподарських рослинах, внаслідок чого збільшується надходження їх в організм людини і тварин [6].

При несприятливій екологічній ситуації на організм людини впливає декілька токсичних чинників, що може супроводжуватись виникненням оксидативного стресу в організмі з подальшим розвитком поліорганної патології [7].

У результаті оксидативного стресу, який виникає при токсичних ураженнях, в організмі накопичуються продукти пероксидного окиснення ліпідів (ПОЛ) та ендогенні токсини, що є однією з причин розбалансування регуляції гомеостазу 
і призводить до серйозних метаболічних порушень, зміни імунного статусу, порушення фрункціонального стану різних систем $[8,9]$.

Не викликає сумніву використання за даних умов засобів, які б виводили з організму токсичні продукти екзо- та ендогенного походження. Зазвичай у таких випадках використовують ентеросорбенти. На особливу увагу заслуговує вуглецевий ентеросорбент IV покоління "Карболайн", що складається з вуглецевих волокон АУТ-М з питомою поверхнею пор близько 2000-2500 м²/r [10, 11].

Мета дослідження - оцінити есрективність використання ентеросорбенту "Карболайн" та його вплив на окиснювальні процеси в організмі щурів різного віку, уражених натрію нітритом на тлі 30-денної тютюнової інтоксикації.

МЕТОДИ ДОСЛІДЖЕННЯ. Експерименти проведено на білих безпородних щурах-самцях, яких утримували на стандартному раціоні віварію Тернопільського державного медичного університету імені І. Я. Горбачевського. Тварин поділили на три вікові категорії: 1-ша - статевонезрілі 3 масою тіла 60-80 г; 2-га - статевозрілі 3 масою тіла 180-200 г; 3-тя - старечі з масою тіла 300-320 г. Кожна вікова група складалася 3 двох підгруп - інтактний контроль та дослідна група. Щурів дослідних груп протягом 30 днів піддавали впливу тютюнового диму (ТД). Піддослідних тварин поділили ще на чотири групи. Щурам 1-ї групи за 24 год до закінчення експерименту вводили натрію нітрит (НH) у дозі 45 мг/кг маси тіла, 2-ї - натрію нітрит за 72 год до евтаназії. Тваринам ще двох груп після ураження обома токсикантами інтрагастрально вводили ентеросорбент “Карболайн” у дозі 400 мг/кг маси тіла протягом 15 днів (починаючи з 15 дня інтоксикації тютюновим димом і щодня до кінця експерименту). Модель залежності від хронічної дії тютюнового диму створювали за допомогою герметичної камери об'ємом 30 л, що дозволило обкурювати тварин у вільній поведінці. Тютюновий дим, що утворювався від горіння 6 сигарет "Прима срібна (синя)" (з вмістом 0,6 мг нікотину та 8 мг смоли), через отвори у камері подавали всередину неї. У камері одночасно перебувало 6 щурів протягом 6 хв. Тварини контрольної групи також знаходились протягом 6 хв у герметичній камері, але не підлягали дії тютюнового диму.

Через 30 діб від початку ураження тварин тютюновим димом їх виводили з експерименту шляхом евтаназії під тіопенталовим наркозом.

Для дослідження брали кров, сироватку крові, печінку, легені та міокард тварин. Із дослідних тканин готували $10 \%$ гомогенат на ізотонічному розчині.
Вміст активних форм кисню (АФК) визначали в нейтрофрілах крові за методом [12]. Популяцію нейтрофрілів крові отримували за допомогою центрифругування на подвійному градієнті щільності 1,077 і 1,093 фіколу-верографіну. Після 40 хв центрисругування при температурі $4{ }^{\circ} \mathrm{C}$ і швидкості 1500 об./хв утворювалися дві інтерфрази. Верхня інтерфаза (на межі плазма - верифікол щільністю 1,077) складалася 3 мононуклеарних клітин - 80 \% лімсроцитів, 15-18\% моноцитів і незначного (2-3 \%) додатка гранулоцитів. Нижня інтерфаза (на межі градієнтів розчинів щільністю 1,077-1,092) являла собою на 98-100 \% популяцію нейтрофрілів. Життєздатність клітин у тесті з трипановим синім становила 98-99\%. Аналіз зразків клітин для визначення АФК нейтрофілів проводили на проточному цитометрі Epics XL ("Beckman Coulter", США) за допомогою 2,7-дигідродихлорфлюоресцеїн діацетату. Значення досліджуваного параметра виражали у відсотках (інтенсивність світіння на клітину).

Активність процесів ліпопероксидації оцінювали за вмістом ТБК-активних продуктів (ТБК-АП) [13] у сироватці крові, печінці, міокарді та легенях піддослідних тварин, активність процесів окисної модисрікації білків (ОМБ) - за вмістом 2,4-динітрофенілгідразонів (2,4-ДНФГ) [14] у тих же тканинах.

При виконанні досліджень користувались загальними принципами експериментів на тваринах, узгодженими з положеннями Європейської конвенції про захист хребетних тварин, що використовуються для дослідних та інших наукових цілей [15]. Статистичну обробку отриманих даних проводили за допомогою програми STATISTICA 6,0 з використанням параметричного критерію ANOVA та непараметричного критерію Вілкоксона для зв'язаних вибірок. Зміни вважали достовірними при $p \leq 0,05$ [16].

РЕЗУЛЬТАТИ Й ОБГОВОРЕННЯ. ЗаГаЛЬНОвідомо, що будь-який адаптивний або патологічний процес відбувається на тлі утворення активних форм кисню та інтенсифрікації вільнорадикального окиснення біосубстратів [9, 14]. Надмірне продукування АФК або порушення нормального фрункціонування систем антиоксидантного захисту викликає посилене окиснювальне ушкодження біомолекул, що призводить до розвитку оксидативного стресу та диссрункції клітин і тканин організму. Виникнення оксидативного стресу спричинюється дисбалансом між утворенням АФК та можливістю біологічної системи швидко детоксикувати окисник або усувати ушкодження. Вважають, що посилення процесів пероксидного окиснення вказує на 
порушення захисно-пристосувальних реакцій організму на клітинному рівні та гомеостазу в цілому. Відомо, що АФК можуть ушкоджувати всі компоненти клітин, зокрема ліпіди, структурні та регуляційні білки, вуглеводи, а також ДНК [9].

Ми дослідили вміст АФК у крові щурів, одночасно отруєних натрію нітритом і тютюновим димом, та можливість використання за даних умов ентеросорбенту "Карболайн". Результати наших досліджень наведено в таблиці 1.

Після 30-денного ураження тютюновим димом тварин, отруєних натрію нітритом за 24 та 72 год до закінчення експерименту, в нейтрофрілах крові щурів усіх вікових груп вірогідно $(p \leq 0,05)$ зростав вміст АФК. Найбільше підвищення даного показника зареєстровано у групі статевонезрілих щурів у кінці експерименту, він зріс після ураження у 3 рази, в старечих - у 2,6 раза, статевозрілих - у 2 рази.

Таке підвищення вмісту АФК у крові щурів усіх вікових груп свідчить про розвиток оксидативного стресу в організмі після ураження токсикантами. Найбільш чутливими до них виявились статевонезрілі тварини.

3 метою знешкодження агресивних сполук кисню ми використали ентеросорбент "Карболайн”. У групах тварин усіх вікових категорій після отруєння ТД та 24 год ураження НH карболайн проявив позитивний вплив на вміст АФК - спостерігали тенденцію до зниження даного показника, хоча в жодній групі щурів вірогідних змін стосовно уражених тварин не відзначали. У групах щурів, які протягом 30 днів отруювались ТД і за 72 год до закінчення експерименту отримали НН, вірогідно зменшувався вміст АФК після застосування карболайну (статевонезрілі та старечі тварини) ( $\leq \leq 0,05)$.

Одним із проявів токсичної дії метаболітів кисню є інтенсифрікація реакцій вільнорадикального окиснення. Інтенсифрікація процесів вільнорадикального окиснення під дією АФК приводить до посилення ПОЛ, окисної модифрікації білків, деструкції нуклеїнових кислот, вуглеводів, що спричиняє структурні та метаболічні порушення у клітинах.

Встановлено, що після одночасного ураження щурів усіх вікових груп ТД та НН у сироватці крові й органах активувалися процеси ПОЛ, на що вказував підвищений вміст ТБК-АП у досліджуваних тканинах (табл. 2).

У сироватці крові статевонезрілих щурів вміст ТБК-АП зріс у 1,9 раза після застосування натрію нітриту за 24 год до кінця експерименту (30-та доба тютюнового ураження). При введенні натрію нітриту токсикованим димом тваринам за 72 год до виведення їх з експерименту даний показник підвищився у 2,2 раза. Застосування карболайну протягом 15 днів призвело до зниження вмісту ТБК-АП у сироватці крові статевонезрілих щурів у 1,3 раза в обидва терміни дослідження. У сироватці крові статевозрілих тварин карболайн проявив позитивний вплив на вміст продуктів ліпопероксидації тільки у групі щурів, які отримали натрію нітрит за 24 год до завершення експерименту (зменшився в 1,4 раза). Вірогідне зниження вмісту ТБК-АП $(p \leq 0,05)$ відмічено у двох групах старечих тварин після застосування ентеросорбенту (через 24 год введення НН токсикованим ТД тваринам та через 72 год застосування НН до закінчення експерименту).

У печінці піддослідних щурів усіх вікових груп не спостерігали еорективного впливу карболайну в перший термін дослідження (30 днів ураження ТД+24 год отруєння НН). Вірогідних змін не відмічено, але зареєстровано тенденцію до зниження даного показника. Ефективним виявилось застосування карболайну в групах тварин, які отримували НН за 72 год до завершення інтоксикації ТД. У печінці щурів усіх вікових категорій вміст ТБК-АП у цей термін вірогідно зменшувався порівняно з ураженими тваринами.

Таблиця 1 - Вміст активних форм кисню (\%) у нейтрофрілах крові щурів різного віку, уражених натрію нітритом на тлі 30-денної інтоксикації тютюновим димом та після застосування карболайну $(\mathrm{M} \pm \mathrm{m}, \mathrm{n}=90)$

\begin{tabular}{|c|c|c|c|}
\hline \multirow{2}{*}{ Термін дослідження, доба } & \multicolumn{3}{|c|}{ Група піддослідних тварин } \\
\hline & статевонезрілі щури & статевозрілі щури & старечі щури \\
\hline Інтактні щури & $15,06 \pm 0,71$ & $18,47 \pm 0,22$ & $19,87 \pm 0,86$ \\
\hline $\begin{array}{l}\text { 30-та доба ураження ТД+ } \\
24 \text { год отруєння НН }\end{array}$ & $43,52 \pm 1,47^{\star}$ & $32,53 \pm 0,74^{*}$ & $46,47 \pm 0,53^{*}$ \\
\hline $\begin{array}{l}\text { 30-та доба ураження ТД+ } \\
24 \text { год отруєння НН+карболайн }\end{array}$ & $37,55 \pm 2,14$ & $30,21 \pm 2,91$ & $41,14 \pm 2,20$ \\
\hline $\begin{array}{l}\text { 30-та доба ураження ТД+ } \\
72 \text { год отруєння НH }\end{array}$ & $45,78 \pm 0,84^{*}$ & $37,86 \pm 0,67^{*}$ & $52,18 \pm 1,20^{*}$ \\
\hline $\begin{array}{l}\text { 30-та доба ураження ТД+ } \\
72 \text { год отруєння НН+карболайн }\end{array}$ & $36,66 \pm 2,64$ ** & $35,29 \pm 2,68$ & $36,99 \pm 2,21^{\star \star}$ \\
\hline
\end{tabular}

Примітка. Тут і в наступній таблиці: * вірогідні зміни між інтактними тваринами та щурами, ураженими токсиканта-

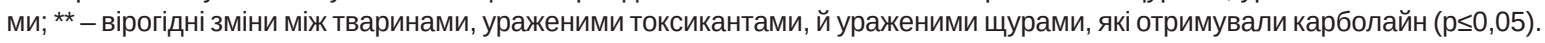


Таблиця 2 - Вміст ТБК-активних продуктів у сироватці крові (мкмоль/л) та органах (мкмоль/кг) щурів різного віку, уражених натрію нітритом на тлі 30-денної інтоксикації тютюновим димом та після застосування карболайну $(\mathrm{M} \pm \mathrm{m}, \mathrm{n}=90)$

\begin{tabular}{|c|c|c|c|}
\hline \multirow{2}{*}{ Термін дослідження, доба } & \multicolumn{3}{|c|}{ Група піддослідних тварин } \\
\hline & статевонезрілі щури & статевозрілі щури & старечі щури \\
\hline & \multicolumn{3}{|c|}{ Сироватка крові } \\
\hline Інтактні щури & $3,28 \pm 0,23$ & $1,85 \pm 0,14$ & $2,35 \pm 0,14$ \\
\hline $\begin{array}{l}\text { 30-та доба ураження ТД+ } \\
24 \text { год отруєння НН }\end{array}$ & $6,21 \pm 0,32^{*}$ & $5,57 \pm 0,31^{*}$ & $6,57 \pm 0,21^{*}$ \\
\hline $\begin{array}{l}\text { 30-та доба ураження ТД+ } \\
24 \text { год отруєння НН+карболайн }\end{array}$ & $4,66 \pm 0,30$ ** & $3,85 \pm 0,24^{\star *}$ & $5,18 \pm 0,23^{\star \star}$ \\
\hline $\begin{array}{l}\text { 30-та доба ураження ТД+ } \\
72 \text { год отруєння НН }\end{array}$ & $7,14 \pm 0,31^{*}$ & $6,00 \pm 0,24^{*}$ & $7,43 \pm 0,21^{*}$ \\
\hline \multirow[t]{2}{*}{$\begin{array}{l}\text { 30-та доба ураження ТД+ } \\
72 \text { год отруєння НH+карболайн }\end{array}$} & $5,67 \pm 0,27^{* *}$ & $5,48 \pm 0,17$ & $5,01 \pm 0,33^{* *}$ \\
\hline & \multicolumn{3}{|c|}{ Печінка } \\
\hline Інтактні щури & $15,49 \pm 1,28$ & $14,42 \pm 0,71$ & $16,55 \pm 0,98$ \\
\hline $\begin{array}{l}\text { 30-та доба ураження ТД+ } \\
24 \text { год отруєння НН }\end{array}$ & $34,61 \pm 1,00$ & $32,26 \pm 1,25^{*}$ & $36,75 \pm 1,22^{*}$ \\
\hline $\begin{array}{l}\text { 30-та доба ураження ТД+ } \\
24 \text { год отруєння НН+карболайн }\end{array}$ & $33,25 \pm 1,07$ & $28,84 \pm 1,14$ & $33,01 \pm 1,07$ \\
\hline $\begin{array}{l}\text { 30-та доба ураження ТД+ } \\
72 \text { год отруєння НН }\end{array}$ & $44,44 \pm 0,91^{*}$ & $36,21 \pm 1,36^{*}$ & $45,98 \pm 1,03^{*}$ \\
\hline \multirow[t]{2}{*}{$\begin{array}{l}\text { 30-та доба ураження ТД+ } \\
72 \text { год отруєння НН+карболайн }\end{array}$} & $33,00 \pm 1,49^{\star *}$ & $29,93 \pm 1,25^{\star \star}$ & $39,00 \pm 1,38 * *$ \\
\hline & \multicolumn{3}{|c|}{ Легені } \\
\hline Інтактні щури & $18,66 \pm 0,60$ & $21,82 \pm 1,51$ & $21,36 \pm 2,13$ \\
\hline $\begin{array}{l}\text { 30-та доба ураження ТД+ } \\
24 \text { год отруєння НН }\end{array}$ & $37,81 \pm 1,10^{\star}$ & $42,30 \pm 1,13^{\star}$ & $47,00 \pm 1,62^{*}$ \\
\hline $\begin{array}{l}\text { 30-та доба ураження ТД+ } \\
24 \text { год отруєння НН+карболайн }\end{array}$ & $35,90 \pm 2,96$ & $39,96 \pm 2,13$ & $38,03 \pm 2,77^{* \star}$ \\
\hline $\begin{array}{l}\text { 30-та доба ураження ТД+ } \\
72 \text { год отруєння НН }\end{array}$ & $39,95 \pm 1,47^{*}$ & $47,47 \pm 1,73^{\star}$ & $54,37 \pm 2,07^{*}$ \\
\hline \multirow[t]{2}{*}{$\begin{array}{l}\text { 30-та доба ураження ТД+ } \\
72 \text { год отруєння НН+карболайн }\end{array}$} & $36,43 \pm 1,38$ & $44,65 \pm 2,25$ & $46,47 \pm 1,97^{\star \star}$ \\
\hline & \multicolumn{3}{|c|}{ Міокард } \\
\hline Інтактні щури & $9,72 \pm 0,65$ & $13,35 \pm 0,98$ & $13,35 \pm 1,28$ \\
\hline $\begin{array}{l}\text { 30-та доба ураження ТД+ } \\
24 \text { год отруєння НН }\end{array}$ & $29,69 \pm 1,12^{*}$ & $26,07 \pm 1,08^{\star}$ & $32,58 \pm 1,04^{\star}$ \\
\hline $\begin{array}{l}\text { 30-та доба ураження ТД+ } \\
24 \text { год отруєння НН+карболайн }\end{array}$ & $25,10 \pm 1,04^{\star *}$ & $24,25 \pm 0,97$ & $26,38 \pm 1,27^{\star \star}$ \\
\hline $\begin{array}{l}\text { 30-та доба ураження ТД+ } \\
72 \text { год отруєння НН }\end{array}$ & $32,79 \pm 1,53^{*}$ & $30,55 \pm 1,43$ & $37,92 \pm 1,04^{*}$ \\
\hline $\begin{array}{l}\text { 30-та доба ураження ТД+ } \\
72 \text { год отруєння НН+карболайн }\end{array}$ & $30,23 \pm 1,01$ & $24,04 \pm 0,96^{\star \star}$ & $29,38 \pm 0,74^{\star *}$ \\
\hline
\end{tabular}

Вірогідне зниження $(\mathrm{p} \leq 0,05)$ вмісту продуктів пОЛ у легенях токсикованих двома чинниками тварин після застосування карболайну відмічено тільки в старечих щурів. У цих же тварин карболайн мав найбільш ефеективний вплив на міокард. У статевонезрілих щурів він виявився ефрективним тільки в групі, яка була отруєна натрію нітритом за 24 год до закінчення інтоксикації ТД (30-та доба). У статевозрілих тварин застосування карболайну призвело до вірогідного зниження вмісту ТБК-АП у міокарді тільки в тій групі, яка отримувала $\mathrm{HH}$ за 72 год до завершення експерименту.

Білкові молекули також $є$ мішенями для атаки АФК, що призводить до зміни їх вторинної та третинної структури, агрегації та фррагментації [7]. У зв'язку з особливостями хімічної будови і структурної організації протеїнів, процес ОМБ має складний характер, що пов'язано з утворенням великої кількості окиснених продуктів радикальної та нерадикальної природи. Дія АФК на білки може спричиняти утворення ковалентних зв'язків як безпосередньо в молекулі, так і між сусідніми молекулами. У літературі є дані про те, що конорормаційні зміни у структурі молекул білків, які відбуваються при їх взаємодії з АФК, збільшують доступність пептидних зв'язків для дії протеїназ [7]. АФК можуть впливати на процеси внутрішньоклітинної деградації білків не лише шляхом модифікації структури молекул 
білків, але й шляхом зміни рівноваги між протеазами та їх інгібіторами.

Визначення вмісту продуктів ОМБ нейтрального та основного характеру в сироватці крові й органах щурів, уражених досліджуваними токсикантами, показало їх збільшення у всіх групах тварин.

Карболайн проявив позитивний вплив на вміст показників ОМБ нейтрального характеру в сироватці крові піддослідних щурів усіх вікових груп (рис. 1).

Після застосування карболайну відмічено тенденцію до зниження продуктів ОМБ у печінці, легенях та міокарді тварин, вірогідних змін практично не спостерігали.

Через 24 год після потрапляння натрію нітриту в організм токсикованих димом щурів у сироватці крові вміст 2,4-динітрофенілгідразонів нейтрального характеру (2,4-ДНФГ $\left.{ }_{370}\right)$ після застосування карболайну зменшувався у всіх вікових групах однаково - на 50 \%. В останній термін дослідження (72 год отруєння НH та 30 днів ураження ТД) більш виражене зниження даного показника спостерігали в сироватці крові статевозрілих тварин (на 45 \%) після введення карболайну. В статевонезрілих і старечих щурів він зменшився на 25 та 30 \% відповідно.

В органах уражених щурів вираженого зниження 2,4-ДНФГ ${ }_{370}$ після застосування карболайну не спостерігали.

Було вивчено вміст 2,4-динітрофренілгідразонів основного характеру (2,4-ДНФГ $\left.{ }_{430}\right)$ в органах щурів після ураження та застосування карболайну.

Після отруєння натрію нітритом токсикованих тютюновим димом щурів найбільш чутливими виявились тварини статевонезрілого віку. Вміст 2,4-ДНФГ ${ }_{430}$ у щурів даної групи перевищував норму в 3,0-3,3 раза відповідно в досліджувані терміни. Після застосування карболайну спостерігали тенденцію до зниження даного показника, але зміни не були вірогідними. Аналогічну тенденцію відмічено в групах статевозрілих та старечих тварин.

У печінці щурів усіх вікових груп вміст 2,4-ДНФГ ${ }_{430}$ вірогідно зростав, але введення в організм ентеросорбенту не проявило есрективного впливу на даний показник. Аналогічну ситуацію спостерігали в легенях та міокарді уражених тварин після застосування карболайну.

Найбільш ефективний вплив проявив карболайн на вміст 2,4-ДНФГ ${ }_{430}$ у легенях статевонезрілих щурів в обидва терміни дослідження, знижуючи даний показник на 27 \% (рис. 2).

У легенях старечих тварин у перший термін дослідження (30 днів інтоксикації тютюновим димом та 24 год ураження натрію нітритом) даний показник знизився на $12 \%$, а в наступний (30 днів інтоксикації ТД та 72 год отруєння НН) він став на 30 \% меншим від норми.

Отже, застосування карболайну призвело до незначного зниження вмісту продуктів ОМБ у досліджуваних органах і не викликало вірогідних змін у сторону нормалізації даного показника.

ВИСНОВКИ. Ураження щурів різних вікових груп натрію нітритом на тлі 30-денної тютюнової інтоксикації призводить до розвитку оксидативного стресу в організмі, що підтверджується підвищенням у крові вмісту активних фрорм кисню. Агресивні фоорми кисню чинять токсичний вплив на біомакромолекули, в результаті чого спостерігають активацію процесів ліпопероксидації та окисної модиорікації білків. На це вказує збільшення вмісту ТБК-активних продуктів та 2,4-динітрофренілгідразонів як у сироватці крові,

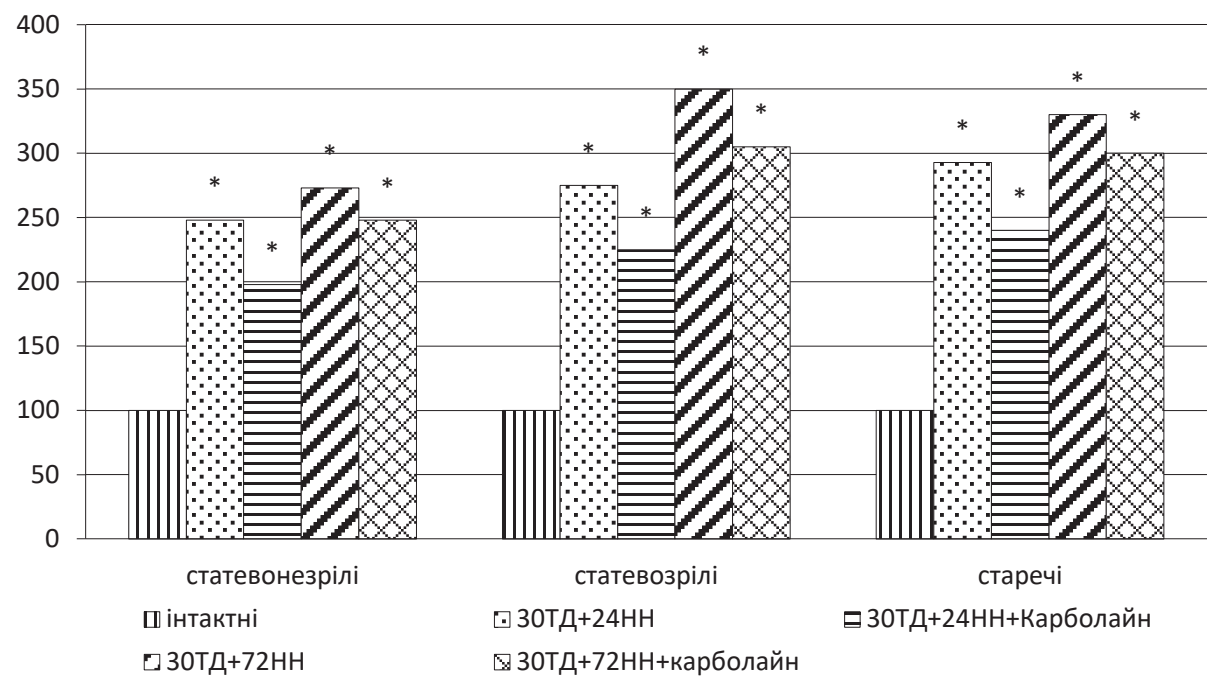

Рис. 1. Вміст продуктів окисної модифікації білків нейтрального характеру (\%) в сироватці крові щурів різних вікових груп, уражених натрію нітритом на тлі тютюнової інтоксикації та після застосування карболайну. 


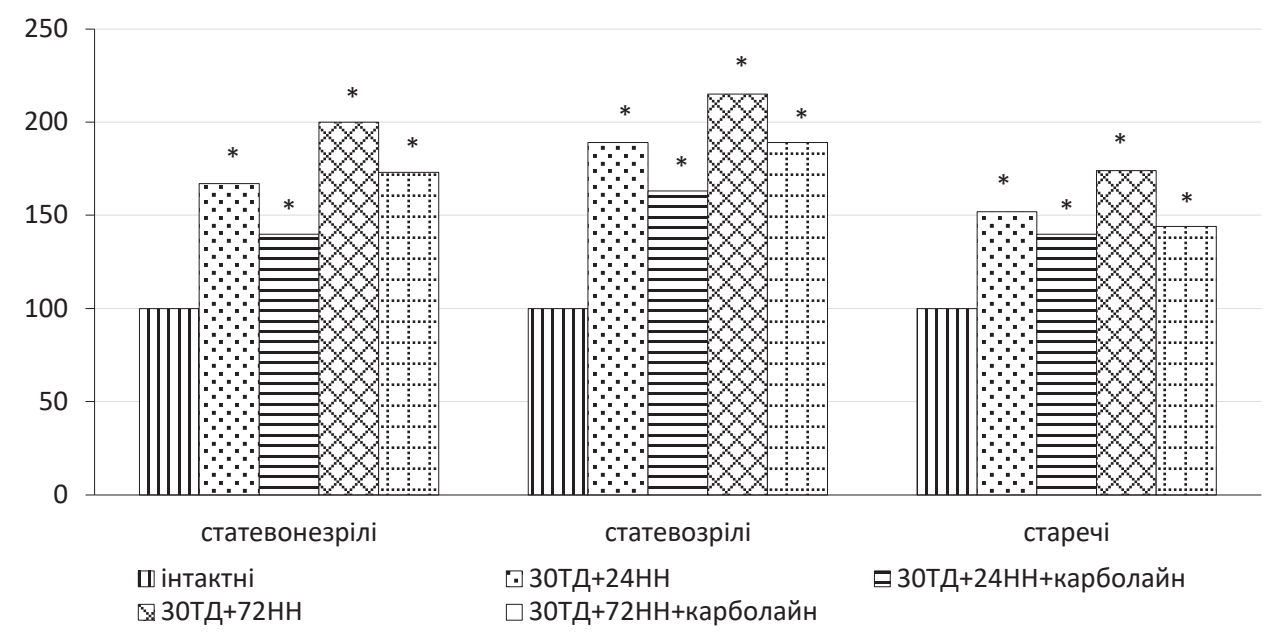

Рис. 2. Вміст продуктів окисної модисікації білків основного характеру (\%) в легенях щурів різних вікових груп, уражених натрію нітритом на тлі тютюнової інтоксикації та після застосування карболайну.

так і в печінці, легенях та міокарді піддослідних тварин. Найбільш чутливі до дії обидвох токсикантів статевонезрілі та старечі щури. Застосування за даних умов карболайну призводить до незначного зниження в організмі тварин активованих вільнорадикальних процесів. Спостерігають тенденцію до зменшення вмісту продуктів ліпопероксидації та окисної модифрікації білків, але вірогідних змін не відмічають. Отримані результати дозволяють запропонувати карболайн як один із компонентів, що може бути включений до загальних схем корекції метаболічних порушень за умов нітратно/нітритних інтоксикацій та отруєнь тютюновим димом.

\section{СПИСОК ЛІТЕРАТУРИ}

1. Москаленко В. Ф. Поширеність тютюнопаління серед молоді: проблеми та шляхи вирішення / В. Ф. Москаленко, Т. С. Грузєва, Л. І. Галієнко // Східноєвроп. журн. громадського здоров'я. -2008. - № 4. C. $71-77$.

2. Тяжка О. В. Пасивне куріння дітей раннього віку / О. В. Тяжка, О. В. Ванханова // Медицина транспорту України. - 2012. - № 1. - С. 93-99.

3. Контроль над тютюном в Україні. Національний звіт [Електронний ресурс]. - К. : МОЗ України, Європейське регіональне бюро ВООЗ, 2009. - 128 с. - Режим доступу : http://moz.gov.ua/ua/main/docs/?doclD= 12871.

4. Smoking prevalence and cigarette consumption in 187 countries / M. Ng. M. Freeman, T. Fleming [et. al.] // JAMA. - 2014. - 311, № 2. - P. 183-192.

5. Пікас О. Б. Про стан куріння цигарок у сучасних умовах, його вплив на виникнення захворювань в організмі людини / О. Б. Пікас // Буковин. мед. вісн. 2015. - 76, № 4. - С. 227-230.

6. Иргашев Т. А. Влияние нитратов на организм человека и животных (обзор) / Т. А. Иргашев, А. И. Каримов. - Душанбе : Нодир, 2009. - 58 с.

7. Paul D. Ray. Reactive oxygen species (ROS) homeostasis and redox regulation in cellular signaling / D. Ray Paul, Huang Bo-Wen, Tsuji Yoshiaki // Cellular Signalling. - 2012. - 24, № 5. - P. 981-990.

8. Huang M. A study of reactive oxygen species in mainstream of cigarette / M. Huang, W. Lin, Y. Ma // Indoor Air. - 2005. - 15, № 2. - P. 135-140.
9. Fruehauf J. P. Reactive oxygen species: a breath of life or death / P. J. Fruehauf, L. F. Meyskens // Clin. Cancer Res. - 2007. - 13, № 1. - P. 789-794.

10. Аналіз адсорбції білокзв'язаних метаболітів і токсинів, характерних для печінкової недостатності, ентеросорбентами різного походження / Л. О. Юшко, В. В. Сарнацька, Л. О. Сахно [та ін.] // Доп. Нац. акад. наук України. - 2009. - № 9. - С. 177-181.

11. Чеснокова Н. П. Молекулярно-клеточные механизмы инактивации свободных радикалов в биологических системах / Н. П. Чеснокова, Е. В. Понукалина, М. Н. Бизенкова // Усп. совр. естествознания. - 2006. - № 7. - С. 29-35.

12. Марущак М. І. Роль активних фрорм кисню у розвитку і прогресуванні гострого ураження легень в експерименті / М. І. Марущак // Мед. хімія. -2012. -14, № 1 (50). - C. 104-108.

13. Лущак В. І. Показники оксидативного стресу. 2. Пероксиди ліпідів / В. І. Лущак, Т. В. Багнюкова, Л. І. Лужна // Укр. біохім. журн. - 2006. - 78, № 5. С. 113-119.

14. Дубініна О. Ю. Окиснювальний стрес і окиснювальна модифрікація білків / О. Ю. Дубініна // Мед. хімія. - 2001. - 3, № 2. - С. 5-12.

15. Gross D. Ethics in Animal-Based Research / D. Gross, R. Tolba // Eur. Surg. Res. - 2015. - 55, № 1-2. - P. 43-57.

16. Okeh U. (2009). Statistical problems in medical research // East. Afr. J. Public. Health. - 6 (1). - P. 1-7. 


\section{REFERENCES}

1. Moskalenko, V.F., Hruzieva T.S. \& Haliienko, L.I. (2008). Poshyrenist tiutiunopalinnia sered molodi: problemy ta shliakhy vyrishennia [The prevalence of smoking among youth: problems and solutions]. Skhidnoievrop. zhurn. hromadskoho zdorovia - Eastern European Journal of Public Health, 4, 71-77 [in Ukrainian]

2. Tiazhka, O.V. \& Vankhanova, O.V. (2012). Pasyvne kurinnia ditei rannoho viku [Passive smoking among young children]. Medytsyna transportu Ukrainy - Transport Medicine of Ukraine, 1, 93-99 [in Ukrainian].

3. Kontrol nad tiutiunom v Ukraini. Natsionalnyi zvit [Tobacco control in Ukraine. National report] (2009). Kyiv: MOZ Ukrainy, Yevropeiske rehionalne biuro VOOZ. Retrieved from: http://moz.gov.ua/ua/main/docs/?doclD= 12871[in Ukrainian].

4. Ng, M., Freeman, M., Fleming, T., Robinson, M., Dwyer-Lindgren, L. \& Thomson, B. (2014). Smoking prevalence and cigarette consumption in 187 countries. JAMA, 311 (2), 183-192.

5. Pikas, O.B. (2015). Pro stan kurinnia tsyharok u suchasnykh umovakh, yoho vplyv na vynyknennia zakhvoriuvan v orhanizmi liudyny [About the level of smoking cigarettes in modern terms, its impact on the occurrence of diseases in humans]. Bukovyn. med. visn. - Bukovynian Medical. Journal, 76 (4), 227-230 [in Ukrainian].

6. Irgashev, T.A. \& Karimov, A.I. (2009). Vliyanie nitratov na organizm cheloveka i zhivotnykh, (obzor) [Effect of nitrates on the human and animal organism]. Dushanbe: Nodir [in Russian].

7. Paul, D. Ray, Huang Bo-Wen\& Tsuji Yoshiaki (2012). Reactive oxygen species (ROS) homeostasis and redox regulation in cellular signaling. Cellular Signalling, 24 (5), 981-990.

8. Huang M., Lin W.\& Ma, Y. (2005). A study of reactive oxygen species in mainstream of cigarette. Indoor Air, 15 (2), 135-140.
9. Fruehauf, J. P. \& Meyskens, L.F. (2007). Reactive oxygen species: a breath of life or death. Clin. Cancer Res., 13 (1), 789-794.

10. Yushko, L.O., Sarnatska, V.V., Sakhno, L.O., Melnyk, V.D., Kornieieva, L.M. \& Nikolaiev V. H. (2009). Analiz adsorbtsii bilokzviazanykh metabolitiv i toksyniv, kharakternykh dlia pechinkovoi nedostatnosti, enterosorbentamy riznoho pokhodzhennia [Analysis of adsorption of protein-bound metabolites and toxins characteristic of liver failure, enterosorbents of various origin]. Dop. Nats. akad. nauk Ukrainy - Reports of the National Academy of Sciences of Ukraine, 9, 177-181 [in Ukrainian].

11. Chesnokova, N.P., Ponukalina, E.V. \& Bizenkova, M.N. (2006). Molekuliarno-kletochnye mekhanizmy inaktivatsii svobodnykh radikalov $v$ biologicheskikh sistemakh [Molecular-cellular mechanisms of inactivation of free radicals in biological systems].Usp. sovr. Estestvoznaniya - Successes of Modern Natural History, 7, 29-35 [in Russian].

12. Marushchak, M.I. (2012). Rol aktyvnykh form kysniu u rozvytku i prohresuvanni hostroho urazhennia lehen v eksperymenti [The role of reactive oxygen species in the development and progression of acute lung injury in experiment]. Med. Khimiia - Medical Chemistry, 14, 104-108 [in Ukrainian].

13. Lushchak, V.I., Bahniukova, T.V. \& Luzhna, L.I. (2006). Pokaznyky oksydatyvnoho stresu. 2. Peroksydy lipidiv [Indicators of oxidative stress. 2. Lipid Peroxides]. Ukr. biokhim. zhurn - Ukrainian Biochemical Journal, 78 (5), 113-119 [in Ukrainian].

14. Dubinina, O.Yu. (2001). Okysliuvalnyi stres $i$ okysliuvalna modyfikatsiia bilkiv [Oxidative stress and oxidative modification of proteins]. Med. khimiia-Medical Chemistry, 2, 5-12 [in Russian].

15. Gross, D., \& Tolba, R. (2015). Ethics in animalbased research. Eur. Surg. Res., 55 (1-2), 43-57.

16. Okeh, U. (2009). Statistical problems in medical research. East. Afr. J. Public. Health., 6 (1), 1-7.

ТЕРНОПОЛЬСКИЙ ГОСУДАРСТВЕННЫЙ МЕДИЦИНСКИЙ УНИВЕРСИТЕТ ИМЕНИ И. Я. ГОРБАЧЕВСКОГО

\section{ПРИМЕНЕНИЕ ЭНТЕРОСОРБЕНТА “КАРБОЛАЙН” ДЛЯ КОРРЕКЦИИ ОКИСЛИТЕЛЬНЫХ ПРОЦЕССОВ У КРЫС РАЗНОГО ВОЗРАСТА, ПОРАЖЕННЫХ НАТРИЯ НИТРИТОМ НА ФОНЕ ТАБАЧНОЙ ИНТОКСИКАЦИИ}

\section{Резюме}

Вступление. Одним из приоритетных направлений токсикологии и медицины является изучение особенностей и механизмов комбинированного действия ксенобиотиков - фракторов риска многих экологически зависимых болезней. Под влиянием экстремальных фракторов различного происхождения (тяжелые металлы, нитраты, пестициды, табакокурение, алкоголь) интенсифицируется образование активных фрорм кислорода (АФК), что приводит к развитию оксидативного стресса в организме, который сопровождается активацией процессов перекисного окисления липидов и окислительной модифрикации белков. В данных условиях широко используют средства с антиоксидантными и сорбтивными свойствами. 
Цель исследования - оценить эфрфективность использования энтеросорбента "Карболайн" и его влияние на окислительные процессы в организме крыс разного возраста, пораженных натрия нитритом на фооне 30-дневной табачной интоксикации.

Методы исследования. В условиях поражения крыс разного возраста натрия нитритом на фроне табачной интоксикации определяли содержание АФК в популяции нейтрофилов крови, полученных с помощью центрифругирования на двойном градиенте плотности 1,077 и 1,093 фрикола-верографрина, содержание ТБК-активных продуктов в реакции с тиобарбитуровой кислотой и окислительную модификацию белков за содержанием 2,4-динитрофренилгидразонов.

Результаты и обсуждение. Самые высокие показатели активности свободнорадикальных процессов отмечены после поражения натрия нитритом за 72 ч до прекращения 30-дневной интоксикации табачным дымом. Неполовозрелые и старые крысы оказались значительно более чувствительными к действию токсикантов, чем зрелые животные. Использованный с челью уднетения активированных окислительных процессов энтеросорбент "Карболайн” незначительно нормализовал исследуемые показатели. Наблюдали тенденцию к снижению содержания АФК в крови, ТБК-активных продуктов и 2,4-динитрофенилгидразонов в исследуемых тканях.

Вывод. Карболайн целесообразно включить в комплексное лечение отравлений различного генеза.

КЛЮЧЕВЫЕ СЛОВА: натрия нитрит; табачный дым; активные формы кислорода; липопероксидация; окислительная модификация белков; карболайн.

P. H. Lykhatskyi, L. S. Fira I. HORBACHEVSKY TERNOPIL STATE MEDICAL UNIVERSITY

\section{SORBENT KARBOLAYN APPLICATION FOR CORRECTION OF PROCESS OXIDATION IN RATS OF DIFFERENT AGRS AFFECTED BY SODIUM NITRITE AGAINST TOBACCO INTOXICATION}

\section{Summary}

Introduction. One of the priorities of toxicology and medicine is the study of the characteristics and mechanisms of action of combined xenobiotics - many risk factors for environmentally dependent diseases. Under the influence of extreme factors of various origins (heavy metals, nitrates, pesticides, tobacco, alcohol), formation of ROS, leading to the development of oxidative stress in the organism, which is accompanied by activation of lipid peroxidation and oxidative modification of proteins is enhanced. Under these conditions antioxidants and sorbents are commonly used.

The aim of the study - to explore efficiency of enterosorbent karbolayn and its effect on oxidative processes in rats of different ages affected by sodium nitrite on the background of the 30-day tobacco intoxication.

Research Methods. Given the defeat of rats of different ages sodium nitrite on the background of tobacco intoxication were tested for the ROS in the population of neutrophils, obtained by centrifugation on a double density gradient 1.077 and 1.093 ficoll-verografin, the content of TBA-active products in reaction with thiobarbituric acid and oxidative modification of proteins 2.4 dynitrofenilhidrazones content.

Results and Discussion. The highest activity of free radical processes was marked after the defeat of sodium nitrite in 72 hours to 30 day of suspension toxicity of tobacco smoke. Immature and old rats were much more sensitive to the action of toxins than mature animals. Immature and old rats were much more sensitive to the action of toxins than mature animals. In order to inhibition of oxidative processes activated sorbent used by us karbolayn led to a slight normalization of the studied parameters. There was a trend toward reduction of reactive oxygen species in blood, TBA-active products and 2.4 dynitrophenilhidrazones in the studied tissues.

Conclusions. The results indicate the advisability of including karbolayn to comprehensive treatment of poisoning of various origins.

KEY WORDS: sodium nitrite; smoke; reactive oxygen species; lipid peroxidation; oxidative modification of proteins; karbolayn.

Отримано 25.04.17

Адреса для листування: П. Г. Лихацький, Тернопільський державний медичний університет імені І. Я. Горбачевського, майдан Волі, 1, Тернопіль, 46001, Україна, e-mail: luhatsky@tdmu.edu.ua. 